\title{
A serological study of primary thymic neoplasms
}

\author{
B. I. HOF F B R A N D \\ From University College Hospital, London
}

New insight into the immunological function of the thymus has added to the significance of the rare primary neoplasms of this organ. It has long been known that thymomas are associated with a high incidence of certain systemic diseases, the best recognized of which are myasthenia gravis (Castleman, 1955), pure red-cell aplasia (Havard and Scott, 1960), and hypo- $\gamma$-globulinaemia (Gafni, Michaeli, and Heller, 1960). Systemic lupus erythematosus, granulomatous myocarditis and myositis, hyper- $\gamma$-globulinaemia, autoimmune haemolytic anaemia, and other conditions have also been described in association with thymic tumours (Miller, 1963 ; Rubin, Straus, and Allen, 1964).

Although the relationship of thymoma to systemic disease is uncertain, immunological mechanisms are probably involved (Miller, Marshall, and White, 1962). There is considerable evidence of autoimmune phenomena in several of the conditions mentioned above ; in particular, a high incidence of antibodies against muscle, nuclei (A.N.F.), and thyroid has been demonstrated recently in myasthenia gravis (van der Geld, Feltkamp, van Loghem, Oosterhuis, and Biemond, 1963 ; Simpson, 1964).

This paper reports an investigation of autoimmune phenomena in sera from 12 cases of primary thymic tumours with and without associated systemic disorder.

\section{MATERIAL AND METHODS}

Details of the 12 patients are given in the Table. Histological confirmation of the diagnosis was obtained in 11 patients; the twelfth had myasthenia gravis with undoubted tomographic evidence of a thymic tumour. One patient (case 6) had a teratomatous thymic tumour (Thomson and Thackray, 1957), and 10 had typical lymphoepithelial growths, predominantly epithelial in six. Three patients (cases 1,2 , and 7) had myasthenia gravis. In case 4 a shoulder girdle myopathy developed five years after radiotherapy for an inoperable growth. At this time also the patient was found to have steatorrhoea and hypertrophic gastritis.

Serum $\gamma$-globulin was estimated by elution of paper electrophoretic strips (Franglen and Martin, 1961) in cases 1 to 9 and by paper electrophoresis with a Chromoscan reflectance densitometer, a cleared correction being made for albumin, in cases 10 to 12 . Total protein was estimated by the biuret method.

A.N.F. and anti-thyroid and anti-gastric parietal cell antibodies were sought by the combined immunofluorescent method using frozen human tissue sections as antigen (Doniach, Roitt, and Taylor, 1963). Fluorescein conjugated goat anti-human globulin antiserum $^{1}$ was used with known positive and negative sera as controls. The method of Feltkamp, van der Geld, and Oosterhuis (1963) was used to look for anti-muscle antibodies. No positive control serum was available, but a more specific fluorescein conjugated goat anti-human $\gamma$-globulin antiserum ${ }^{2}$ was used. These tests were performed in duplicate. The Hyland R.A. latex fixation test was used to look for rheumatoid factor, and the A.N.F.-containing sera were examined with the Hyland L.E. latex nucleoprotein slide test.

\section{RESULTS}

The serum $\gamma$-globulin concentration was normal in all patients except cases 4 and 5 (see Table). The levels in these two patients were slightly raised, compatible with the presence of chronic bronchitis and a large invasive tumour respectively.

A.N.F. was found in three patients, two (cases 1 and 2) with myasthenia gravis. The third (case 12) showed no clinical evidence of autoimmune disease. The other tests performed were all negative. (Titres of A.N.F. depend on too many factors to be meaningful: these positive cases all showed clear nuclear fluorescence.)

1Stayne Laboratories
2Sylvana Co., U.S.A. 
T A B L E

CLINICAL DETAILS AND SERUM $\gamma$-GLOBULIN LEVELS IN 12 PATIENTS WITH PRIMARY THYMIC TUMOURS

\begin{tabular}{|c|c|c|c|c|c|c|}
\hline Case & Ag & ex & Histology & Previous Treatment & Clinical State & Serum \\
\hline 1 & 76 & $\mathrm{~F}$ & - & Radiotherapy & Myasthenia gravis; no & $1 \cdot 01$ \\
\hline 2 & 52 & $\mathbf{M}$ & $\begin{array}{l}\text { Predominantly } \\
\text { epithelial }\end{array}$ & $\begin{array}{l}\text { Radiotherapy; thymectomy; } \\
\text { resection of pleural } \\
\text { metastasis }\end{array}$ & $\begin{array}{l}\text { Myasthenia gravis; pleural } \\
\text { metastasis }\end{array}$ & 0.89 \\
\hline 3 & 36 & $\mathrm{~F}$ & Predominantly & Thymectomy; radiotherapy & Peritoneal metastasis & 1.03 \\
\hline 4 & 64 & $\mathbf{M}$ & $\begin{array}{l}\text { Predominantly } \\
\text { epithelial }\end{array}$ & Radiotherapy & $\begin{array}{l}\text { Chronic bronchitis, myo- } \\
\text { pathy, etc. (see text); }\end{array}$ & $1 \cdot 39$ \\
\hline 5 & 60 & $\mathrm{~F}$ & Predominantly & - & $\begin{array}{l}\text { no recurrence } \\
\text { Inoperable tumour }\end{array}$ & $1 \cdot 49$ \\
\hline 6 & 51 & $\mathbf{M}$ & Teratomatous & Thymectomy & $\begin{array}{l}\text { Symptom-free; no recur- } \\
\text { rence }\end{array}$ & $1 \cdot 20$ \\
\hline 7 & 40 & $\mathrm{~F}$ & $\begin{array}{l}\text { Predominantly } \\
\text { lymphocytic }\end{array}$ & Thymectomy; radiotherapy & $\begin{array}{l}\text { Myasthenia gravis; no } \\
\text { recurrence }\end{array}$ & $1 \cdot 30$ \\
\hline 8 & 51 & $\mathbf{M}$ & $\begin{array}{l}\text { Predominantly } \\
\text { epithelial }\end{array}$ & Radiotherapy & $\begin{array}{l}\text { Symptom-free, no recur- } \\
\text { rence }\end{array}$ & $1 \cdot 19$ \\
\hline 9 & 73 & $\mathbf{F}$ & $\begin{array}{l}\text { Predominantly } \\
\text { epithelial }\end{array}$ & Thymectomy; radiotherapy & $\begin{array}{l}\text { Pulmonary opacities; } \\
\text { ? metastases }\end{array}$ & $1 \cdot 14$ \\
\hline 10 & 38 & $\mathbf{M}$ & Predominantly & Radiotherapy & Inoperable tumour & $1 \cdot 40$ \\
\hline 11 & 52 & $\mathbf{M}$ & $\begin{array}{l}\text { Predominantly } \\
\text { lymphocytic }\end{array}$ & Thymectomy & Symptom-free, no recur- & 0.9 .9 \\
\hline 12 & 56 & $\mathbf{M}$ & $\begin{array}{l}\text { Predominantly } \\
\text { lymphocytic }\end{array}$ & Thymectomy; radiotherapy & $\begin{array}{l}\text { Symptom-free, no recur- } \\
\text { rence }\end{array}$ & $1 \cdot 20$ \\
\hline
\end{tabular}

${ }^{1}$ Normal range: $0.69-1.33$ g. $100 \mathrm{ml}$. (cases 1 to 9 ); 0.6-1.5 g. $100 \mathrm{ml}$. (cases 10 to 12 ).

\section{DISCUSSION}

In no case in this series, albeit small, did the serum $\gamma$-globulin concentration approach subnormal levels. This suggests that circulating antibody production is not frequently depress:d with thymoma. Thus the hypo- $\gamma$-globulinaemia found with thymoma differs from that occurring in chronic lymphatic leukaemia, where although frank hypo- $\gamma$-globulinaemia is rare, over $50 \%$ of cases have a serum $\gamma$-globulin concentration below normal (Fairley and Scott, 1961).

Radiotherapy and thymectomy have, on the whole, little effect on the systemic disorder associated with a thymoma. The clinical response in myasthenia gravis is poor (Henson, Stern, and Thompson, 1965), and no changes in serum $\gamma$-globulin levels occur, after treatment of thymoma associated with hypo- $\gamma$-globulinaemia (Gafni et al., 1960 ; Wollheim, Belfrage, Cöster, and Lindholm, 1964). Nor has thymectomy affected serological evidence of autoimmune phenomena in the occasional case reported, even in the presence of a good clinical response (Birch, Cooke, Drew, London, Mackenzie, and Milne, 1964). It remains a possibility, however, that the treatment which all but one of the present patients had had prior to this study affected the serological findings. Although a high incidence of anti-muscle antibodies has been found in myasthenia gravis associated with a thymoma (van der Geld et al.,
1963), no such antibodies were demonstrated in the present cases.

\section{SUMMARY}

Serum from 12 patients with a primary thymic tumour has been examined from the point of view of autoimmune phenomena. Serum $\gamma$-globulin levels were largely normal, suggesting that hypo$\gamma$-globulinaemia found with thymoma is not a reflection of a frequently occurring depression of circulating antibody production. A.N.F. was found in one patient without clinical evidence of autoimmune disease as well as in two with

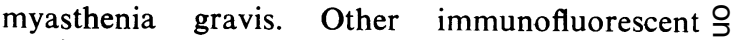
studies and slide latex tests were negative.

There is a need for immunological studies in all cases of thymic tumour before treatment and $\bar{N}$ thus, usually, before histological confirmation of the diagnosis.

My thanks are due to Drs. Gwen Hilton, E. W. O Emery, and J. N. Godlee for access to patients under their care, and to Professor J. F. Smith for the histological details.

\section{REFERENCES}

Birch, C. A., Cooke, K. B., Drew, C. E., London, D. R., Mackenzie D. H., and Milne, M. D. (1964). Hyperglobulinaemic purpura due to a thymic tumour. Lancet, 1, 693 .

Castleman, B. (1955). Atlas of Tumor Pathology, Section V. Fascicle 19: Tumors of the Thymus Gland. Armed Forces Institute of Pathology, Washington, D.C. 
Doniach, D., Roitt, I. M., and Taylor, K. B. (1963). Autoimmune phenomena in pernicious anaemia. Brit. med. J., $1,1374$.

Fairley, G. H., and Scott, R. B. (1961). Hypogammaglobulinaemia in chronic lymphatic leukaemia. Ibid., $2,920$.

Feltkamp, T. E. W., van der Geld, H., and Oosterhuis, H. J. G. H. (1963). Studies on sera from cases of myasthenia gravis, using the fluorescent antibody technique. Vox Sang. (Basel), 8, 317.

Franglen, G., and Martin, N. H. (1961). The paper electrophoresis of serum and urinary proteins. Broadsheet No. 37 (N.S.). Association of Clinical Pathologists.

Gafni, J., Michaeli, D., and Heller, H. (1960). Idiopathic acquired agammaglobulinemia associated with thymoma. New Engl. J. Med., 263, 536.

Havard, C. W. H., and Scott, R. B. (1960). Thymic tumour and erythroblastic aplasia; report of three cases and a review of the syndrome. Brit. J. Haemat., 6, 178.

Henson, R. A., Stern, G. M., and Thompson, V. C. (1965). Thymectomy for myasthenia gravis. Brain, 88, 11 .
Miller, J. F. A. P. (1963). Role of the thymus in immunity. Brit. med. J., $2,459$.

Marshall, A. H. E., and White, R. G. (1962). The immunological significance of the thymus. In Advances in Immunology, Vol. 2, p. 152. Academic Press, New York.

Rubin, M. Straus, B., and Allen, L. (1964). Clinical disorders associated with thymic tumors. Arch. intern. Med., 114, 389.

Simpson, J. A. (1964). Immunological disturbances in myasthenia gravis with a report of Hashimoto's disease developing after thymectomy. J. Neurol. Neurosurg. Psychiat., 27, 485.

Thomson, A. D., and Thackray, A. C. (1957). The histology of tumours of the thymus. Brit. J. Cancer, 11, 348.

Van der Geld, H., Feltkamp, T. E. W., van Loghem, J. J., Oosterhuis, H. J. G. H., and Biemond, A. (1963). Multiple antibody production in myasthenia gravis. Lancet, $2,373$.

Wollheim, F. A., Belfrage, S., Cëster, C., and Lindholm, H. (1964) Primary 'acquired' hypogammaglobulinemia. Acta med. scand. 176, 1. 